\title{
Cervical Cancer pT1a1 TNM Finding v7
}

National Cancer Institute

\section{Source}

National Cancer Institute. Cervical Cancer pT 1a1 TNM Finding V7. NCI Thesaurus. Code C89527.

Invasive cervical cancer with measured stromal invasion $3.0 \mathrm{~mm}$ or less in depth and 7.0 mm or less in horizontal spread. (from AJCC 7th Ed.) 